\title{
Original
}

\section{Alteration of Ultrastructural Localization of Atrial Granules and Changes in Serum Level of $a$-hANP by Atrial Pacing in Patients with Various Heart Diseases}

\author{
Shigeo Hasegawa, Youichi Takeyama, Juichi Hiroshige \\ and Takashi KATAGIRI
}

\begin{abstract}
Alteration of subcellular localization of atrial granules (AGs) and changes in serum level of $\alpha$-human ANP ( $\alpha$-hANP) were studied in twenty patients with various heart diseases by right atrial biopsies and sampling blood from several intracardiac sites before and after atrial pacing at a rate of $150 / \mathrm{min}$ for $20 \mathrm{~min}$. After atrial pacing the mean right atrial pressure (RAP) was significantly increased from $4 \pm 2 \mathrm{mmHg}$ to $6 \pm 2 \mathrm{mmHg}(\mathrm{p}<0.01)$ and pulmonary wedge pressure (PCWP) was also significantly increased from $8 \pm 3 \mathrm{mmHg}$ to $14 \pm 5 \mathrm{mmHg}(\mathrm{p}<0.01)$. The serum level of $\alpha$-hANP in the right atrium (RA) was surprisingly increased from $64 \pm 35$ to $295 \pm 119 \mathrm{pg} / \mathrm{ml}(\mathrm{p}<0.01)$ after RApacing. The response to higher atrial pressures due to pacing caused tremendous secretion of $\alpha$-hANP. The normal value of $\alpha$-hANP level in the peripheral vein in the present study was $27 \pm 11 \mathrm{pg} / \mathrm{ml}$. Electron dense AGs with diameters of 0.3 to $0.4 \mu \mathrm{m}$ were abundant in atrial myocytes in the perinuclear area, especially in the Golgi area before atrial pacing. There were a few in the intermyofibrillar area, but they were scarce in the subsarcolemmal area, which suggested that the granules were produced in the Golgi apparatus. All AGs were confirmed to contain $\alpha$-hANP. In this study the regulation of ANP in response to atrial pacing was elucidated by determining serum concentration of ANP in various cardiovascular sites and ultrastructural alteration of the distribution of atrial granules that contained $\alpha$-hANP identified by immunocytochemistry. This study was performed in the complete absence of heart failure, and there were scarcely any disease specificities, or biased responses of the distribution of AGs in the atria to pacing.
\end{abstract}

Key words: atrial natriuretic peptide, immunocytochemistry, atrial granules, atrial pacing, atrial biopsy

\section{Introduction}

It was first reported by $\mathrm{Kisch}^{1)}$ in 1956 that mammalian atrial muscle cells contain atrial granules (AGs), which are round with diameters of about 0.3 to $0.4 \mu \mathrm{m}$ and electron-dense, but the nature and pathophysiologic roles of AG remained indistinct until recently. In 1982, De Bold $^{2)}$ first demonstrated the biological activity of AG. In anesthetized rats, intraperitoneal administration of atrial extracts caused tremendous diuresis as well as natriuresis. Several physiological actions of AG have been described by many investigators since then, 
and AG was found to contain a hormone called atrial natriuretic peptide (ANP). ANP is secreted in the coronary vein in response to some stimuli; it contributes to the control of blood volume by natriuresis, and to lower blood pressure by relaxing smooth muscle cells of the vascular wall.

In the present study, we examined the relations between alteration of subcellular localization of AGs by right atrial biopsies and changes in serum level of $\alpha$-human ANP ( $\alpha$-hANP) and sampling blood from some intracardiac sites, before and after atrial pacing, in patients with several kinds of heart disease.

\section{Subjects and Methods}

The subjects were 20 patients (16 men, 4 women; 14 to 67 years, $45 \pm 16$ years old; Table 1). There were five cases of cardiomyopathy, four with ischemic heart disease, three with hypertensive heart disease, five with arrhythmias and three with valvular heart disease. Informed consent for this study was obtained from all patients.

Examination protocol: All the cardiovascular drugs were withdrawn for more than 24 hours. A balloon-tipped double-lumen catheter was placed the day before cardiac catheterization, and the catheter was placed into the great cadiac vein (GCV) through the coronary sinus (CS) from the left subclavian vein, so we could simultaneously sample blood separately from the GCV and the CS without affecting insertion of the catheter or stretching the atrial wall.

At the beginning of cardiac catheterization, we first measured hemodynamics as control, and simultaneously sampled blood from the great cardiac vein and the coronary sinus with a double-lumen catheter, from the right atrium and pulmonary artery with a Swan-Ganz catheter, and from the aorta with a pigtail catheter. Serum concentration of $\alpha$-hANP was determined by radioimmunoassay with RAS 8798 Rabbit Anti-Alpha ANP 1-28 (Human, Canine) Serum.

The test sequence was: 1) The first right atrial biopsy was performed as control; 2) the right atrium was paced at a rate of $150 / \mathrm{min}$; 3) after pacing for $20 \mathrm{~min}$ a second biopsy, similar to the first, was performed; 4) a sample of blood was simultaneously taken from the RA to determine the concentration of $\alpha$-hANP.

The right atrial biopsy was carried out from the lateral wall of the right atrium under a posteroanterior view, using a Machida's bioptom introduced througuh a 9F Lehman's sheath catheter. The examination was terminated by diagnostic left ventriculography and coronary angiography. Statistical analysis was carried out by paired $t$-test. A difference of $\mathrm{P}$ less than 0.05 was considered to be significant.

Table 1. Subjects.

20 consenting cases underwent cardiac catheterization.

\begin{tabular}{lccc}
\multicolumn{1}{c}{ Diseases } & Cases & Average ages & Sex: M/F \\
\hline Hypertrophic cardiomyopathy & 5 & $48 \pm 12$ & $5 / 0$ \\
Ischemic heart diseases & 4 & $55 \pm 7$ & $4 / 0$ \\
Hypertensive heart diseases & 3 & $28 \pm 14$ & $2 / 1$ \\
Arrhythmic diseases & 5 & $50 \pm 19$ & $3 / 2$ \\
Valvular diseases, etc. & 3 & $37 \pm 5$ & $2 / 1$ \\
$\quad$ Total & 20 & $14-67(45 \pm 16)$ & $16 / 4$ \\
\hline
\end{tabular}


Preparation for electron microscopy: The tissue samples were taken from the right atrium of each patient. Immediately after the right atrial biopsy, all tissue $\left(1 \mathrm{~mm}^{3}\right)$ was prefixed in a cold $2 \%$ glutaraldehyde solution containing $0.1 \mathrm{M} \mathrm{Na-cacodylate}(\mathrm{pH} 7.4)$ for $1 \mathrm{hr}$ at $4^{\circ} \mathrm{C}$. After rinsing with $0.1 \mathrm{M} \mathrm{Na}$-cacodylate $\left(\mathrm{pH} \mathrm{7.4)}\right.$ for $1 \mathrm{hr}$ at $4^{\circ} \mathrm{C}$, the samples were dehydrated in a graded series of ethanol and propylene oxide, and embedded in a mixture of Epon 812-Araldite. Ultrathin sections were cut on a Porter Blum MT-2 microtome and double-stained with uranyl acetate and lead citrate. The specimens were then examined in a Hitachi H-300 electron microscope (Table 2-left).

Immunocytochemical procedures: Ultrathin sections were mounted on 200-mesh nickel grids prepared for the immunocytochemical reaction described in Table 2 (right) as the immunocytochemical method. The grids were pretreated for $10 \mathrm{~min}$ at room temperature with saturated solution of sodium metaperiodate for deosmification to enhance antigeneity to immunocytochemical reaction, and then immersed in Na-phosphate buffer solution (PBS) (0.01 M, $\mathrm{pH} 7.2$ ) with $0.5 \%$ bovine serum albumin for $15 \mathrm{~min}$. They were immersed in a primary antibody solution, anti rabbit $\alpha$-hANP antiserum (dilution 1/500, Peninsula Laboratories, Belmont, CA., Peninsula Labs, specification leaflet, 1984), overnight at $4{ }^{\circ} \mathrm{C}$. This antibody shows cross-reactivity to $\alpha$-hANP, rat-atriopeptin III, rat ANP and 8-33ANP but only slightly

Table 2. Methods for electron microscopy.

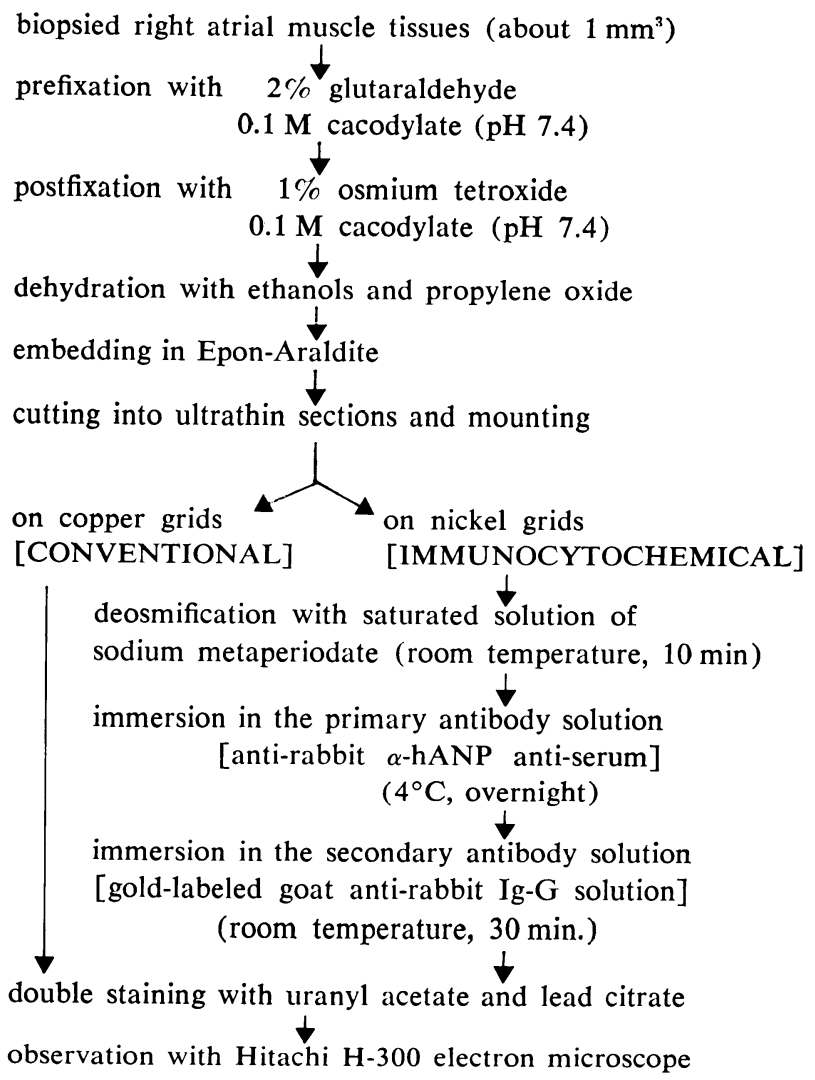


to BNP. The meshes were then rinsed in PBS 3 times for 15 min each time. They were then incubated in a secondary antibody solution, gold-labeled goat anti-rabbit Ig-G solution (dilution 1/50, Janssen Life Sciences Products, Beerse, Belgium), for $30 \mathrm{~min}$ at room temperature, and again rinsed 3 times in PBS. Finally, they were washed in distilled water, and doublestained with uranyl acetate and lead citrate. In control experiments no immunostaining was observed when primary antisera were omitted, replaced with non-immune serum, or preabsorbed with their corresponding antigens for the same antisera.

These specimens were inspected in a Hitachi H-300 electron microscope.

\section{Results}

Hemodynamic alteration: As shown in Fig. 1, the mean right atrial pressure (RAP) was significantiy increased from $4 \pm 2 \mathrm{mmHg}$ to $6 \pm 2 \mathrm{mmHg}(\mathrm{p}<0.01)$, and pulmonary wedge pressure (PCWP) from $8 \pm 3 \mathrm{mmHg}$ to $14 \pm 5 \mathrm{mmHg}(\mathrm{p}<0.01)$.

Serum level of $\alpha-h A N P$ : As shown in Table 3, the serum concentrations of $\alpha$-hANP before pacing were $358 \pm 294 \mathrm{pg} / \mathrm{ml}$ in the coronary sinus, $130 \pm 100$ in the great cardiac vein (GCV), $64 \pm 35$ in the right atrium (RA), $41 \pm 25$ in the pulmonary artery, and $41 \pm 21 \mathrm{pg}$ / $\mathrm{ml}$ in the aorta (AO).

The level was much higher in the CS than in any other cardiovascular site, even significantly higher than that in the GCV. This indicates secretion of peptide from the atria, but not from the ventricles.

The serum level of $\alpha$-hANP in RA was surprisingly increased from $64 \pm 35$ to $295 \pm 119$ $\mathrm{pg} / \mathrm{ml}(\mathrm{p}<0.01)$ as a response to higher pressures in atria $20 \mathrm{~min}$ after RA-pacing. The normal value of $\alpha$-hANP level in the peripheral vein determined by RIA used in the present study was $27 \pm 11 \mathrm{pg} / \mathrm{ml}$.

Ultrastructural localization of atrial granules: In the atrial myocytes before atrial pacing, electron dense AGs with diameters of about 0.3 to $0.4 \mu \mathrm{m}$ were abundant in the perinuclear area. There were many in the Golgi apparatus and a few in the intermyofibrillar area, but they were scarce in the subsarcolemmal region (Fig. 2-a, b). This suggests that the granules

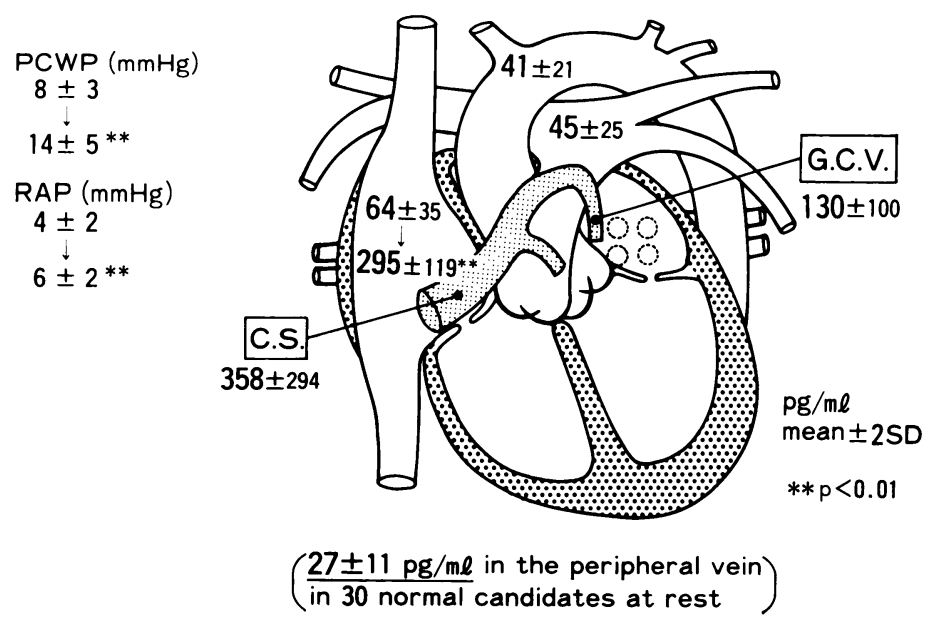

Fig. 1. Diagram of heart showing change of pulmonary wedge pressure (PCWP), right atrial pressure (RAP), and serum levels of $\alpha$-hANP. 

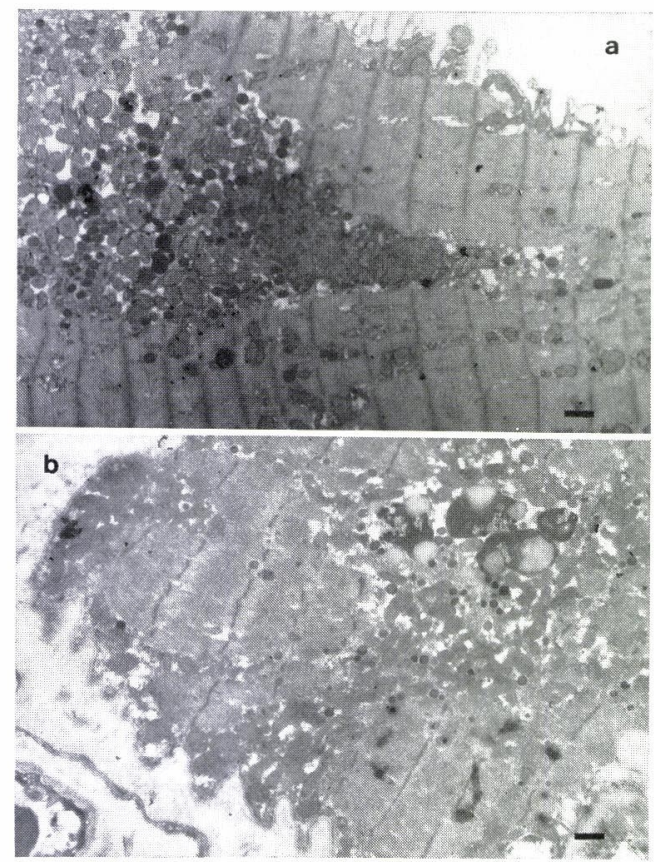

Fig. 2. Part of a right atrial cell before pacing.

$\mathrm{a}$ and b: Electron-dense atrial 0.3 to $0.4 \mu \mathrm{m}$ diameter granules are seen scattered in the intermyofibrillar area and a few in the subsarcolemmal area. Bar: $1 \mu \mathrm{m}$.

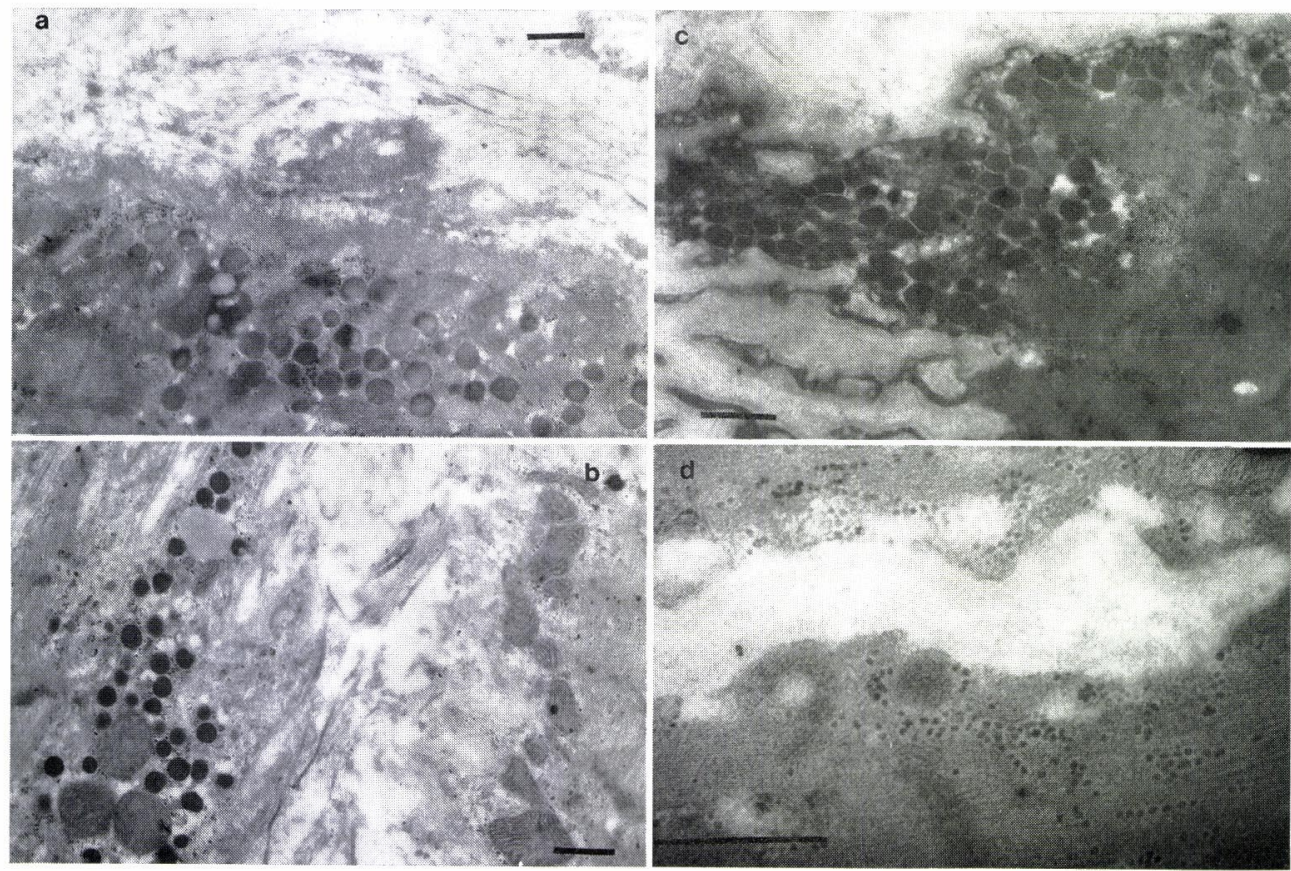

Fig. 3. After $20 \mathrm{~min}$ of atrial pacing.

a, b and c: Atrial granules tended to be found in increased numbers in the subsarcolemmal area after pacing. d: Atrial granules suggesting exocytosis. Bar: $1 \mu \mathrm{m}$. 


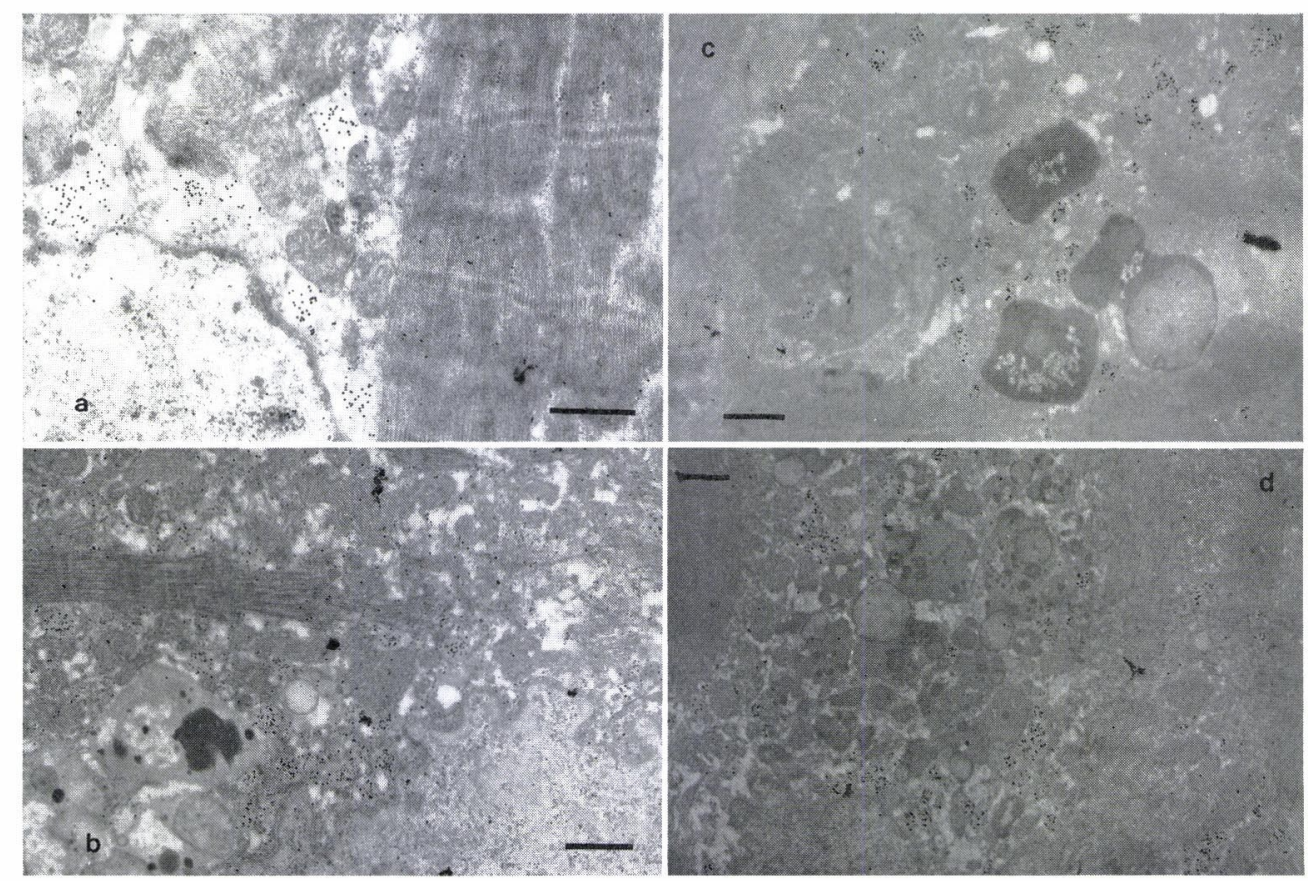

Fig. 4. $\alpha$-hANP-like immunoreactive atrial granules in the perinuclear area before pacing. $\mathrm{a}$ and b: Immunocytochemically reacted gold particles are recognized richly and specifically on all the atrial granules. $\mathrm{c}$ and $\mathrm{d}$ : No $\alpha$-hANP-positive gold particles were recognized on lipofuscin granules, lysosomes nor on any other organelles. Bar: $1 \mu \mathrm{m}$.

were produced in the Golgi apparatus.

On the other hand, $20 \mathrm{~min}$ after atrial pacing, AGs tended to increase in number in the subsarcolemmal area (Fig. 3-a, b). Sometimes, they were concentrated (Fig. 3-c) and appeared to be slightly exocytosed (Fig. 3-d).

Immunocytochemistry: Protein A-gold (10 nm diameter) was used as a marker for demonstration of immunoreaction of $\alpha$-hANP. Several electron-dense gold particles were specifically found on the AGs recognized in myocytes in the perinuclear area before pacing (Fig. 4-a, b). These were less electron-dense and somewhat faded because of deosmification to enhance immunoreactivity of the granules. However, no $\alpha$-hANP-positive gold particles were recognized on lipofuscin granules, lysosomes, residual bodies or any other organelles in the atrial muscle celis (Fig. 4-a, b). They revealed higher immuno-specificity for ANP in our study. All AGs were confirmed to contain $\alpha$-hANP.

Figure 5 ( $\mathrm{a}, \mathrm{b}$ and $\mathrm{c}$ ) shows increased $\alpha$-hANP-positive AGs in the subsarcolemmal area, which was possibly moved from Golgi area to this region by atrial pacing.

In some control studies, no immunostaining was observed in similarly treated reactions except for exclusion of the primary antibody solution and a few gold particles found randomly scattered on the myocyte examined by absorption test using $\alpha$-hANP containing solution as shown in Fig. 6.

This study was performed in the complete absence of heart failure, and there were scarcely any disease specificities, or biased responses of the distribution of AGs in the atria to pacing. 

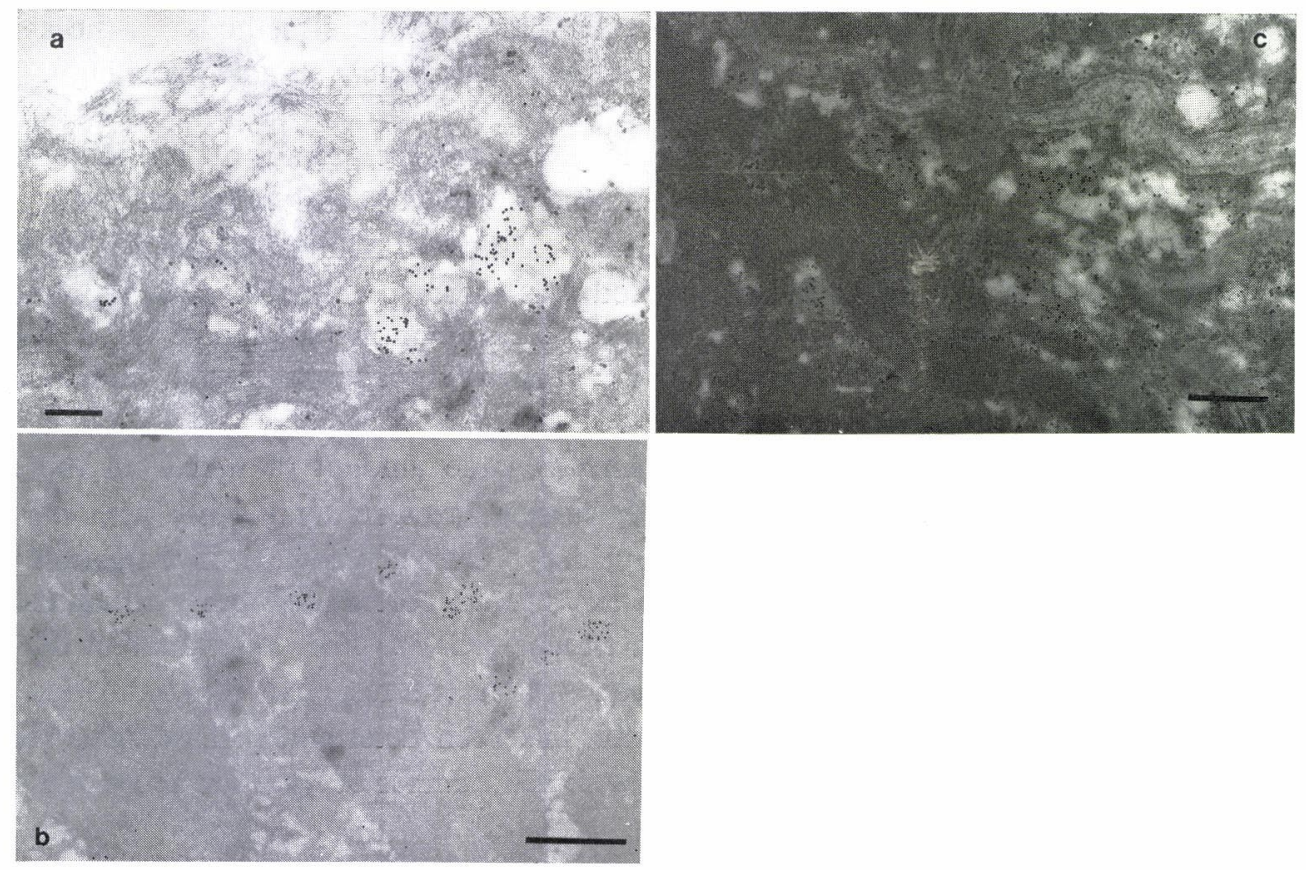

Fig. 5. a, b and c: Increased number of $\alpha$-hANP-positive atrial granules in the subsarcolemmal area. Bar: $1 \mu \mathrm{m}$.

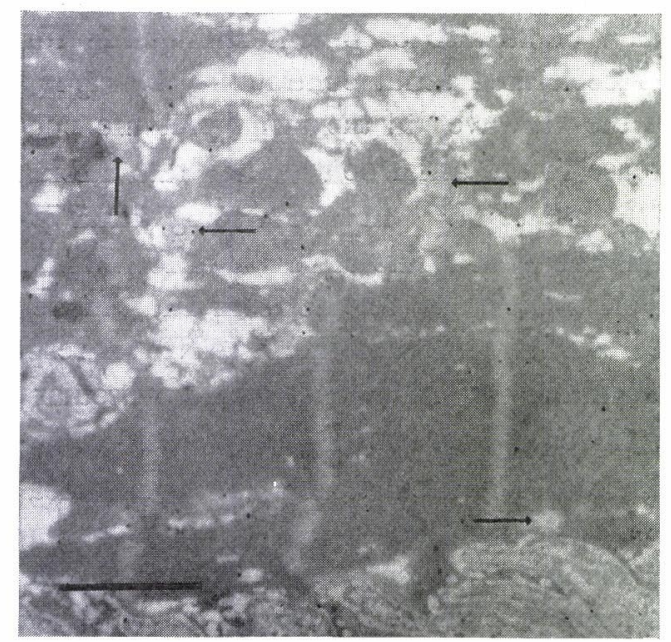

Fig. 6. Part of an atrial cell observed in absorption test. Few immunoreacted gold particles are seen in the intermyofibrillar area. Atrial granules are evidently free of gold particles (arrows). Bar: $1 \mu \mathrm{m}$.

\section{Discussion}

The association of ANP with the specific atrial granules of the rat heart has been previously indicated by using differential and sucrose density gradient ultracentrifugation studies of rat heart homogenates ${ }^{2,3)}$. Localization of ANP in the granules has been demonstrated in ex- 
perimental animals by immunocytochemical peroxidase-antiperoxidase methods ${ }^{4-6)}$, the avidinbiotin peroxidase method $^{(1)}$, and by electron microscopical protein A-gold labelling ${ }^{4)}$. The same results were observed by our group ${ }^{8)}$.

In the present study we examined the immunocytochemical evidence of hANP utilizing the protein A-gold method for biopsied human atrial myocytes and found all AGs were exclusively immuno-positive with many gold particles on them. Immunocytochemical evidence of AGs containing hANP obtained by our method was more specific than that reported by others $^{4,9,10)}$; deosmification with a saturated solution of sodium metaperiodate for $10 \mathrm{~min}$ to enhance the antigenicity of AGs showed few non-specific reactions in our immunocytochemistry.

We demonstrated that atrial myocytes contained a large amount of hANP in the AGs by sampling blood obtained from the main cardiovascular sites simultaneously with the biopsied atrial myocytes before and during atrial pacing. Our histological investigation was confined to biopsied right atrial cells, because it has been reported that other atrial tissues, such as appendages and left atrial cells, contain similar $\mathrm{AGs}^{11)}$. The importance of the role of the atria in releasing ANP and regulating blood volume in response to stimulation has recently been considered. The manner of secretion has been determined in previous studies using experimental animals ${ }^{12-14}$. We observed a simılar manner of secretion in human atrial cells, suggesting exocytosis.

The following important stimuli of ANP secretion from atrial cells have been described: 1) An increase in atrial pressure has been reported by many investigators to be a principal stimulus for the release of ANP, with volume loading observed in both experimental and clinical studies ${ }^{15-21)}$. 2) Atrial wall stretching by volume overload ${ }^{22)}$ or by occluding pulmonary veins with balloons ${ }^{23)}$ could also be potent stimulation for ANP release in experimental investigations. 3) Accelerated atrial contractility by right atrial pacing, reflected by the increased amplitude of the "a wave" in the atrial pressure curve, is a possible factor in releasing $\mathrm{ANP}^{2+)}$. 4) Increase in the atrial contraction rate itself may induce secretion of ANP, as documented by Haufe et al. ${ }^{25)}$ in 1987 using atrial pacing.

In the present study, atrial pacing at a rate of $150 / \mathrm{min}$ for $20 \mathrm{~min}$ involved all of the major factors described above to stimulate ANP release from atrial myocytes.

Our results clarified the regulatory mechanism of ANP in response to atrial pacing by determining serum concentrations of ANP in all cardiovascular sites, including the great cardiac vein and coronary sinus, and by showing ultrastructural alteration of the distribution of AGs confirmed by immunocytochemical techniques to specifically contain $\alpha$-hANP.

The higher serum level of $\alpha$-hANP after atrial pacing in humans may be closely related to a state caused by spontaneous atrial tachycardia which results in higher atrial pressures and gives rise to increased urine excretion, thought to be due to the accelerated secretion of ANP, a potent to natriuretic, from AGs.

\section{Acknowledgements}

The authors thank Professor Yasumitsu Nakai of Showa University School of Medicine for his encouragement during this work, which was partly supported by a grant from the Tanaka Memorial Foundation (1980).

\section{References}

1) Kisch B: Electron microscopy of the atrium of the heart. Exp. Med. Surg, 14: 99-112 (1956) 
2) De Bold AJ: Tissue fractionation studies on the relationship between an atrial natriuretic factor and specific atrial granules. Can J Physiol, 60: 324-330 (1982)

3) Garcia R, Cantin M, Thibault G, Ong $\mathbf{H}$ and Genest $\mathbf{J}$ : Relationship of specific granules to the natriuretic and diuretic activity of rat atria. Experientia, 38: 1071-1073 (1982)

4) Cantin M, Gutkowska J, Thibault G, Milne RW, Ledoux S, MinLi S, Chapeau C, Garcia R, Hamet P and Genest $\mathbf{J}$ : Immunocytochemical localization of atrial natriuretic factor in the heart and salivary glands. Histochemistry, 80: 113-127 (1984)

5) Saper CB, Standaert DG, Schwartz D, Currie MG, Geller DM and Needleman P: Atriopeptin-immunoreactive neurons in the brain: presence in cardiovascular regulatory areas. Science, 22: 10471049 (1985)

6) Vuolteenao $O$, Arjamaa $O$, Jarvinen $M$ and Rinne A: Atrial natriuretic factor: Immunohistochemical localization in the specific atrial granules of the rat heart. Acta Histochem, 77: 199-203 (1985)

7) Has SM, Raine L and Frange $\mathrm{H}$ : Use of avidin-biotin-peroxidase complex (ABC) in immunoperoxidase techniques: a comparison between $\mathrm{ABC}$ and antibody (PAP) procedures. $J$ Histochem Cytochem, 29: 577-580 (1981)

8) Hiroshige J, Takeyama Y, Hasegawa S and Katagiri T: Changes in subcellular distribution of atrial granules after atrial pacing in canine atrial muscle cells. Showa Univ J Med Sci, 4: 189-201 (1992)

9) Gilloteaux J: Ultrastructural aspects of atrium development: demonstration of endocardial discontinuities and immunolabeling of atrial natriuretic factor in Syrian hamster. Anat Embryol, 179: 227236 (1989)

10) Skepper JN and Navaratnam V: Analysis of the apparent heterogeneity of specific heart granules in rat atrial myocytes; an ultrastructural study including immunocytochemistry. Histochem J, 20: $1-10$ (1988)

11) Rinne A, Vuolteenaho O, Jarvinen M, Dorn A and Arjamaa O: Atrial natriuretic polypeptides in the specific atrial granules of the rat heart: immunohistochemical and immunoelectron microscopical localization and radioimmunological quantification. Acta Histochem, 80: 19-28 (1986)

12) Page E, Goings GE, Power B and Earley JU: Ultrastructural features of secretion. Am J Physiol, 251: H340-H348 (1986)

13) Skepper JN, Navaratnam V and Martensz ND: Effects of expansion of blood volume and bilateral vagotomy on specific heart graunles and release of natriuretic peptide in the rat. Cell Tissue Res, 258: 211-218 (1989)

14) Toshimori H, Toshimori K, Minamino N, Kangawa K, Oura C, Matsukura S and Matsuo $H$ : Chicken atrial natriuretic peptide (chANP) and its secretion. Cell Tissue Res, 259: 293-298 (1990)

15) Lang RE, Tholken H, Ganten D, Luft FC, Ruskoaho $\mathbf{H}$ and Unger Th: Atrial natriuretic factora circulating hormone stimulated by volume loading. Nature, 314: 264-266 (1985)

16) Eskay R, Grojec ZZ, Haas M, Dave JR and Zamir N: Circulating atrial natriuretic peptide in conscious rats; regulation of release by multiple factors. Science, 232: 636-639 (1986)

17) Yamaji $T$, Ishibashi $M$ and Takaku F: Atrial natriuretic factor in human blood. J Clin Invest, 76: 17u5-1709 (1985)

18) Tunny TJ, Gordon RD, Klemm SA and Hamlet SM: Effects of acute volume expansion on atrial natriuretic peptide levels in normal subjects, primary aldosteronism and low-renin essential hypertension. J Hypertension, 4 (suppl 6): S509-S511 (1986)

19) Sagnella GA, Markandu ND, Shore AC and MacGregor GA: Changes in plasma immunoreactive atrial natriuretic peptide in response to infusion or to alterations in dietary sodium intake in normal subjects. J Hypertension, 4 (suppl 2): S115-S118 (1986)

20) Anderson JV, Donckier J, McKenna WJ and Bloom SR: The plasma release of atrial natriuretic peptide in man. Clin Sci, 71: 151-155 (1986)

21) Kojima S, Inoue I, Hirata Y, Saito F, Yoshida K, Abe H, Deguchi F, Kawano Y, Kimura G, Yoshimi H, Yokouchi M, Kuramochi M, Ito $\mathrm{K}$ and Omae $\mathrm{T}$ : Effects of changes in dietary sodium intake and saline infusion on plasma atrial natriuretic peptide in hypertensive patients. Clin Exp Hypertens [A], 9: 1243-1258 (1987)

22) Dietz JR: Release of natriuretic factor from rat heart-lung preparation by atrial disteation. $A m$ J Physiol, 160: R1093-R1096 (1984)

23) Ledsome JR, Wilson N, Courneya CA and Rankin AJ: Release of atrial natriuretic peptide by 
atrial distention. Can J Physiol Pharmacol, 63: 739-742 (1985)

24) Goldreyer BN, Kastor JA and Kershbaum KL: The hemodynamic effects of induced supraventricular tachycardia in man. Circulation, 54: 783-789 (1976)

25) Haufe MC, Weil J, Nafzger K, Gerzer R, Bidlingmaier F and Theisen K: Acute increase in right atrial pressure by intracardiac stimulation releases atrial natriuretic peptide. Eur Heart J, 8: 277-281 (1987)

[Received July 16, 1992: Accepted July 27, 1992] 